\title{
THE DICCIONARIO INGLÉS-ESPAÑOL DE CONTABILIDAD: TRADUCCIÓN AND THE DICCIONARIO INGLÉS-ESPAÑOL DE CONTABILIDAD: TRADUCCIÓN DE FRASES Y EXPRESIONES: TWO SPECIALISED DICTIONARIES FOR TRANSLATING TERMS AND COLLOCATIONS
}

\author{
Pedro A. Fuertes-Olivera \\ pedro@tita.emp.uva.es \\ International Centre for Lexicography (University of Valladolid, Spain) \\ Sandro Nielsen \\ sn@asb.dk \\ Centre for Lexicography (University of Aarhus, Denmark) \\ International Centre for Lexicography (University of Valladolid, Spain) \\ Henning Bergenholtz \\ hb@asb.dk \\ Centre for Lexicography (University of Aarhus, Denmark) \\ Department of Afrikaans and Dutch (University of Stellenbosh, South Africa) \\ International Centre for Lexicography (University of Valladolid, Spain)
}

\begin{abstract}
This paper focuses on the role dictionaries play in a translation situation. This role is analysed in terms of the tenets of the Function Theory of Lexicography, which proposes that users do not have needs in general but punctual needs in specific situations. For example, translators of accounting texts need insertable equivalents whose meanings and language behaviour are clearly described. Furthermore, translators also need contextual data on domain-specific consensual usage. The construction of the Accounting Dictionaries and Diccionarios de Contabilidad reveals that the Function Theory offers theoretical and practical solutions for constructing dictionaries that target user needs
\end{abstract}


in a precise way (Fuertes-Olivera \& Tarp 2014). For example, two recent accounting dictionaries, the Diccionario Inglés-Español de Contabilidad: Traducción and Diccionario Inglés-Español de Contabilidad: Traducción de Frases y Expresiones, offer precise dictionary data for disambiguating the meaning of English accounting terms, their Spanish equivalents and their use in real English and Spanish accounting texts.

\section{Résumé}

Cet article est centré sur le rôle des dictionnaires en situation de traduction. Ce rôle est analysé suivant les principes de la Théorie Fonctionnelle de la Lexicographie, qui établit que les utilisateurs n'ont pas des besoins généraux, mais des besoins ponctuels en situations spécifiques d'utilisation. Ainsi les traducteurs de textes comptables ontils besoin d'équivalents insérables, dont le sens et le comportement langagier sont minutieusement décrits. En outre, les traducteurs ont également besoin de données contextuelles illustrant les usages discursifs conventionnalisés du domaine de spécialité. La construction des Accounting Dictionnairies and Diccionarios de Contabilidad - dictionnaires de comptabilité - révèle que la Théorie Fonctionnelle apporte des solutions théoriques et pratiques à la construction de dictionnaires parfaitement ciblés sur les besoins des utilisateurs (Fuertes-Olivera \& Tarp 2014). Par exemple, deux récents dictionnaires de comptabilité, le Diccionario Inglés-Español de Contabilidad: Traducción et le Diccionario Inglés-Español de Contabilidad: Traducción de Frases y Expresiones, offrent tous deux des données dictionnairiques précises pour désambiguiser le sens des termes de comptabilité anglais, leurs équivalents espagnols, et leur mise en discours dans des textes de comptabilité anglais et espagnols authentiques.

Keywords: Function theory. Specialised translation. English. Spanish. E-lexicography. User needs

Mots-clé: Théorie fonctionnelle. Traduction spécialisée. Anglais. Espagnol. E-lexicographie. Besoins de l'utilisateur 


\section{Introduction}

An analysis of the term user needs in the literature on specialised dictionaries, especially in connection with terminological needs for translation purposes, indicates that there are three main approaches dealing with this concept. The first approach is based on the British tradition (see Householder 1962) and relies on data extracted from dictionary usage surveys. This approach investigates users' degree of satisfaction with their dictionaries and users' performance when consulting one or other dictionary (type) (Josselin-Leray \& Roberts 2005).

Josselin-Leray and Roberts explain that their survey's main goal was to obtain data for improving the treatment of terminology in general dictionaries by ensuring that user needs are met. The description of the work carried out illustrates the rationale for the questionnaires used, which were addressed to three different types of users: language specialists, scientific or technical experts, and the general public. It also explains the methodology adopted in such works: sending questionnaires to the above-mentioned informants and analysing the answers received, without using sampling techniques for selecting informants and adapting their answers accordingly.

We do not believe that this approach is adequate for identifying user's needs for several reasons. It suffices to indicate that the methodology used in most usage surveys is an ad-hoc methodology without scientific backing (Tarp 2009). Researchers in the Social Sciences have explained the requirements questionnaires and surveys must meet for being considered scientifically sound and for accepting their conclusions. For instance, a questionnaire designed for students in a particular place (between 20 and 80 is a normal tally) only reflects these students' views, and these views cannot be generalised unless the informants are described as a sample of the whole population, something that is never done.

The second approach to studying user needs is what we call a terminological approach and is typically found in discussions concerned with information tools presented as terminographical products, such as terminological (knowledge) bases, glossaries, terminological data banks, ontologies, word lists, etc. 
(see L'Homme 2006 and Fuertes-Olivera \& Tarp 2014, for a discussion). This approach has always had translators' needs in mind (e.g., Davidson 1991), but it has presented such needs in a very broad and general way, i.e., without specifying which types of users and in which types of situations the information tools are expected to be consulted. In other words, user needs are taken for granted but never discussed, as shown in Dancette (2011).

Dancette's proposals aim at assisting both translators and language learners in specialised fields. She presents two dictionaries -the Analytical Dictionary of Retailing and the Analytical Dictionary of Globalisation and Work- and a methodology for creating them, which relies on linguistics assumptions and can be summarised as follows: Dancette (2011) argues that what users need is the acquisition and organisation of knowledge of the conceptual field, and adds that this can be achieved provided the dictionary includes a large number of semantic relations (SRs), which are uncovered by analysing corpus data. For instance, the dictionary description of travailleur migrant includes a definition, and a description of types and other encyclopaedic data on migrant workers. These are based on semantic relations that are presented as hierarchical relations, e.g., travailleur mobile; associative relations, e.g., migration transnationale; syntagmatic relations, e.g., migrer; and equivalent relations, e.g., English migrant worker and Spanish trabajador migrante. For the field of retailing, Dancette's dictionary offers a structured and organised presentation of the most important concepts in the field, i.e., 3,500 English and 3,500 French terms covered and described in 350 detailed articles.

This second approach can be criticised on several counts, of which two are sufficient for this paper: (i) it does not break down user needs into specific needs in specific usage situations nor define the concept of needs; (ii) it uses a misguided methodology as linguistics assumptions and methods are inadequate for compiling real specialised dictionaries (see Fuertes-Olivera \& Tarp, for a discussion). For instance, although scholars have been working in the DiCoInfo project for more than 20 years, they have only completed around 1,000 articles in French and around 700 articles in English. We believe that this is because DiCoInfo's underlying methodology is based on Mel'čuk's concept of lexical functions, which cannot be used for describing most of the lexicographic data that must be present in real specialised dictionaries (Pimentel, L'Homme \& Laneville 2012: 180).

The third approach to examining user needs is a functional approach, which is based on the function theory of lexicography. According to this approach, the core of lexicography is the design of utility tools that can be accessed and consulted easily with a view to meeting punctual information needs occurring 
for specific types of users in specific types of extra-lexicographical situations (see Bergenholtz \& Tarp 2002, 2003, 2004; Fuertes-Olivera \& Tarp 2014; Tarp 2008; and Tono 2010 for a revision). The functional approach therefore identifies the existence of different types of potential users whose needs have to be addressed by defining the dictionary as an information tool (Section 2), adequate for specific users in a specific type of usage situation (Section 3), here illustrated with the presentation of two dictionaries whose primary users are translators (Section 4). A final conclusion summarizes the main points discussed.

\section{Dictionary Concepts and Translation}

Do dictionary users know what a dictionary is? The answer can be both yes and no. If we answer "yes", then we are saying that all native speakers will understand the following: Please pass me the big blue dictionary over there at the back of the table. If the answer is "no", we imply that hardly any ordinary language user is able to define the word dictionary clearly or accurately. Furthermore, ordinary language users do not know precisely whether a lexicon and a word list are the same as a dictionary, or what exactly constitutes the difference (if any) between these terms. And when such ordinary mother-tongue speakers say they know the answer, it will soon become apparent that different people offer quite different definitions. Each person will nevertheless insist that their definition is correct. In this respect they are no different from experts, nor from the descriptions of the word dictionary -which are as numerous as the dictionaries themselves and often problematic or even downright incorrect or both.

We will give two definitions found on the Internet and refer to Bergenholtz (2012) for a longer discussion. The first one sees a dictionary as an information tool with certain data types:

a reference that tells you the meanings, parts of speech, sometimes a sentence using the word, and how to pronounce the word

(http://wiki.answers.com/Q/A_definition_for_dictionary, found 4 May 2012)

Such a definition excludes many information tools we normally consider to be dictionaries: a spelling dictionary normally does not contain definitions, specimen sentences and pronunciation items; according to the first definition, a spelling dictionary is not a dictionary. A frequency dictionary, which lists only word forms and their frequency, would not be worthy of the designation dictionary either; neither would a bilingual dictionary, which in most cases does not explain the meanings of words. The reason why this widespread and inaccurate definition is found in so many variants may be that so many people 
have blindly repeated it, orally and in writing. To be a little more positive, one could regard it as the definition of a monolingual polyfunctional dictionary. This is the type of dictionary that is often regarded as THE dictionary, but it is really a very special type of dictionary -the kind that linguists and linguists claiming to be lexicographers view as the sole object of lexicography. It is a very narrow view of what a dictionary is, as it covers those that are aimed only at solving communication problems (text production, text reception and translation), and in this case not even at translation. Such dictionaries are also called 'language dictionaries'. Many lexicographers regard such dictionaries with communicative functions as the only object for lexicography.

The second definition is more convincing as it mentions translation as a function:

A dictionary is a book of words of a particular language and their accepted definitions, origins, parts of speech, pronunciation, spelling and in some cases a sample of their use. Depending on the age and target audience, it may also contain cultural slang and/or other non-traditional words as well. A "language translation dictionary" lists the words of one language and their equivalent words in another language. (http://wiki.answers.com/Q/What_ is_a_dictionary, found 5 May 2012).

The above definition takes into account that a dictionary is an information tool, since 'language translation dictionary' is mentioned. But even so, it would be a relatively basic translation dictionary, since only equivalence items are mentioned; no translated collocations, no translated competence examples and no contrastive notes. But still, also excluded in this case is the type of reference work that is usually called a biscopal dictionary, a dictionary with words from language A translated into language $B$ as well as from language $\mathrm{B}$ into language $\mathrm{A}$. It could also be argued that a biscopal dictionary is not a single dictionary, but two dictionaries, though this is not common practice. It should also be noted that this definition uses the expression "a book of words". That is not what it is, of course; it is "a book of dictionary articles". There are lemmas, or headwords, for which different data are provided. The misunderstanding may be due to the fact that the English term "entry" is used to refer to the lemmas as well as to the 'articles' in a dictionary. However, this does not fully explain the misunderstanding. A dictionary entry ('article') is never called a 'word' in English, and ordinary novels are "books of words".

A more realistic typology takes into account that a dictionary is an information tool to be used in different usage situations and contains lemmas from different kinds of language. The most important difference is that between general language and specialised language, as illustrated in Figure 1. 


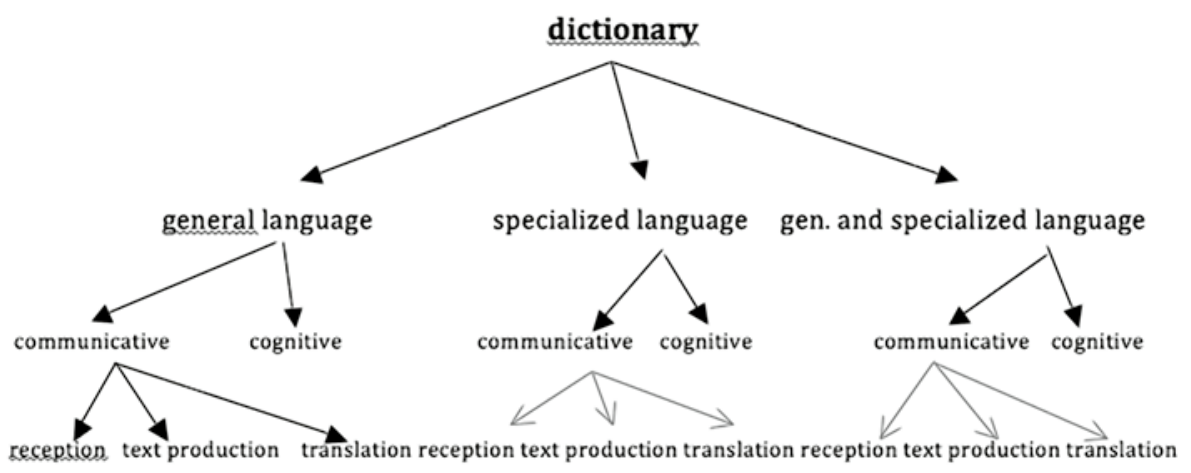

Figure 1: Typology of dictionaries

After the criticisms of existing definitions of 'dictionary', it may appear somewhat presumptuous to propose one. We will propose one nevertheless - and not just one, but two, as it has become clearer that 'dictionary' has not just one, but two distinctly different meanings in the same way as other polysemous words. Bergenholtz (2012: 30) offers these two definitions of 'dictionary':

1. A dictionary is a lexicographic reference work containing dictionary articles related to individual topics or elements of language, and possibly several outer texts as well, which can be consulted if someone needs assistance with text reception, text production or translation or would simply like to know more about a word, part of a word or a combination of words.

2. A dictionary is a lexicographic reference work consisting of several dictionaries, each of which corresponds to the definition of an individual dictionary, i.e. a reference work containing dictionary articles related to individual topics or elements of language, and possibly several outer texts as well, which can be consulted if someone needs assistance with text reception, text production or translation or would simply like to know more about a word, part of a word or a combination of words.

These two very general definitions do not contain the notion of monolingual or bilingual dictionaries, but only the different functions of lexicographic tools. The focus on language is of course important, but not directly related to functions: a bilingual dictionary is not equivalent to a translation dictionary. Bilingual dictionaries can of course be used in translation situations, but bilingual dictionaries can also be used as reception dictionaries for Lb-users 
(with Lb for the foreign language and La for the native language). They can also be used as tools in text production situations for Lb-users. Finally, bilingual dictionaries with definitions can be used to acquire knowledge about special or general objects.

In a similar vein, this paper distinguishes between different kinds of bilingual translation dictionaries, e.g.:

1. bilingual dictionaries with only lemmas and equivalents;

2. bilingual dictionaries with only lemmas + grammar items and equivalents + grammar items;

3. bilingual dictionaries with only lemmas and equivalents and with translated collocations;

4. bilingual dictionaries with all known types of items: lemmas, equivalents, grammar items, synonym items, collocations, competence examples, etc.

There are many additional possibilities. We know from experience that dictionary types (1) and (4) are used in many cases. The question is not which one is the most useful kind of bilingual dictionary for translation problems, but rather which one is the most useful for which type of user or which type of usage situation?

\section{User Needs in a Translation Situation}

Translation dictionaries designed to satisfy usage needs require a sound lexicographic foundation. This will allow compilers to respond directly to lexicographically relevant needs by making dictionaries that have translation functions. According to Bergenholtz \& Tarp (2010: 30), a lexicographic function is "the satisfaction of the specific types of lexicographically relevant needs that may arise in a specific type of potential user in a specific type of extra-lexicographical situation". The types of situation in which dictionaries may be helpful are many and translation dictionaries have two main types of functions: communicative functions where dictionaries provide help in ongoing or planned communicative situations, and cognitive functions where dictionaries provide help when translators want to acquire knowledge. The functions of specialised translation dictionaries can be summarised as follows:

- to provide help to translate specialised texts into and from specific languages;

- to provide help to produce specialised texts in one or more specific languages; 
- to provide help to understand specialised source texts to be translated;

- to provide help to acquire general or specific knowledge about domain-specific matters in specific languages and domains.

This list of possible dictionary functions is non-exhaustive, and it is important to understand that dictionary functions concern needs that arise in usage situations that are unrelated to dictionaries. For example, persons who are translating specialised texts are in an extra-lexicographic environment as they act as translators and are merely potential dictionary users. While translating, they may encounter problems specifically related to their task and think they can solve them by consulting a dictionary. Once they consult the dictionary, translators have moved into the lexicographic environment and are now actual dictionary users. When they have found the answers to their questions, they leave the lexicographic environment and go back to their tasks in the translation environment. The usage situations that gave rise to the dictionary consultation are completed, and the translators are now potential dictionary users again. The translators may come across new translation problems and consult a dictionary -a new usage situation arises- and this may be repeated several times until the translation tasks have been completed. Having said that, it is necessary to link usage situations and user needs to user types.

The various competences and levels of competence dictionary users have play a significant role. Lexicographers can get an idea of the relevant competences by dividing users into general groups, and according to Nielsen (1990: 131) and Bergenholtz \& Kaufmann (1997: 98-99) it is appropriate to distinguish between experts, semi-experts and laypeople. The levels of competence of these three groups indicate the lexicographically relevant user needs, as the members of these user groups have different factual, linguistic, text production and translation competences, so the dictionaries need to contain data that help users where competences are inadequate. Bergenholtz \& Nielsen (2006: 285) suggest that one way in which to ensure that users get the help they need is to identify their characteristics by answering a number of questions in a diagnostic checklist:

- Which language is their native language?

- At what level do they master their native language?

- At what level do they master a foreign language?

- How extensive is their experience in translating between the languages in question?

- What is the level of their general cultural and factual knowledge?

- At what level do they master the special subject field in question? 
- At what level do they master the relevant LSP in their native language?

- At what level do they master the relevant LSP in the foreign language?

- At what level do they master translation of specialised texts between the languages in question?

- At what level do they master translation theories, methods and strategies?

The answers to the above questions will show which competences the target group of the dictionary has and enable lexicographers to put data into the dictionary that will help users where the competences are insufficient. The usefulness of specialised translation dictionaries depends on their capability of supporting the translation process and traditional bilingual dictionaries used for the translation of specialised texts are characterised by containing domain-specific terms in the source language and their equivalents in the target language (Haensch 1991: 2939-2942). However, a study of terms in specialised texts from a number of subject fields reveals that terms generally make up less than 20 per cent of the texts (Laurén 1993: 99-100). In other words, the traditional specialised dictionary with its focus on terms and terminological equivalence provides help to translate a small part of specialised texts. It is therefore necessary to look closer at the translation process in an attempt to identify some of the needs specialised translation dictionaries must fulfil to help users produce acceptable translations of entire texts.

One approach is to consult the research literature on translation. Several translation scholars have looked into the elements of the translation process, and some of their findings are relevant for translating specialised texts. Nord (2005) demonstrates that the translation process involves several recursive steps that go beyond the level of terms and words, and Bell (2000: 211) explicitly emphasises the orientation towards larger translation units by describing syntactic, semantic and pragmatic knowledge as necessary elements in translating. This is further accentuated by Nord (2005), who recognises that translation problems occur at clause and sentence levels:

The structural differences between two languages, particularly in lexis and sentence structure, give rise to certain translation problems which occur in every translation involving this pair of languages, no matter which of the two serves as source and which serves as target language. (Nord 2005: 175)

Compared with usage surveys, findings by translation scholars have several benefits for theoretical and practical lexicography. First, the findings represent types of general elements of the translation process instead of individual, one-off results. Second, translation scholars are experts in translating texts 
and have considerable practical as well as theoretical experience of the translation process, which may lead to the inclusion of data types in translation dictionaries that can help translators solve general types of problems instead of idiosyncratic problems. Finally, specialised translation dictionaries that take these findings into account will address user needs on an objective basis instead of catering for subjective needs.

An objective approach to user needs reveals that specialised translation dictionaries should include terms as well as linguistic units larger than terms, one of which is generally referred to as collocations. There are various linguistic definitions of this type of word combinations; similarly specialised lexicographers and terminologists do not agree on a generally applicable definition either, referring to co-occurrences, phraseologisms, specialised lexical combination, etc. Nevertheless, lexical combinations that are used in specialised communication are relevant for translators because they are integral parts of domain-specific consensual usage in both source and target languages. Moreover, translators need help to translate such word combinations due to differences in semantic and syntactic properties which are caused by specific referential foci within the factual structure of domains, and therefore "native speakers of a language cannot rely exclusively on their intuition to produce correct combinations; they must reproduce usages that have been defined within specific subject fields" (L'Homme 2009: 238).

Lexical units combining with terms are relevant for inclusion in dictionaries designed to provide help with translation for several reasons. First, words known from general language often occur in specialised texts in combination with terms and have meanings that differ from their every-day meanings. The word 'recognise' is found in financial reporting texts in association with terms, e.g. 'recognise assets'. Translators cannot rely on their general-language competence when coming across this type of word combinations since 'recognise' has a meaning different from what may be expected: to include an asset in the balance sheet for the purpose of financial reporting. Second, the words used in association with terms may differ from one language to another even though they express the same thing, as in the English collocation 'to set up a committee', which corresponds to the Danish collocation 'nedsætte et udvalg' [literally: set down a committee]. Third, terms may combine with other lexical units according to linguistic structures in the source language that differ from the structures in the target language. The English collocation 'the consideration received' is translated into Spanish as a similar post-modified construction, 'la contraprestación recibida', whereas the Danish translation requires a pre-modified construction, 'det modtagne vederlag'. Fourth, terms in 
one language may correspond to collocations or phrases in another language. A company that adopts the International Financial Reporting Standards in its annual report for the first time is called a 'first-time adopter', which is a term in English. The equivalent concept is expressed as an explanatory collocation or phrase in Danish, 'virksomhed, som anvender IFRS for første gang' ['enterprise that adopts IFRS for the first time'], whereas Spanish has two options: 'adoptante por primera vez', which is a term, and 'entidad que adopta por primera vez las NIIF', which is an explanatory collocation or phrase. Finally, the translation of specialised collocations may depend on the translation strategy adopted by the translator. For example, the Danish collocation 'vælge en revisor' has two correct translations in English: a source-language oriented translation, 'elect an auditor', and a target-language oriented translation, 'appoint an auditor', which is the acceptable way of expressing this in British English when an auditor is chosen by a company in a general meeting.

Terms and the collocations in which they occur should not be selected for inclusion in translation dictionaries because they fit into one or other linguistic typology or categorisation. They should be included because they satisfy the need of translators based on the competences they have as profiled above; i.e. terms and collocations that are difficult to translate because they fall within one of the five categories described above should be in translation dictionaries as their presence would provide help to translation. The important point is to make these data easily available to and easily understandable by dictionary users.

\section{The Accounting Dictionaries}

Modern technology allows lexicographers to make dictionaries in many shapes and sizes, in particular as electronic information tools. The Accounting Dictionaries are a set of monolingual and bilingual online dictionaries with the languages Danish, English and Spanish, each with its own communicative or cognitive function. These information tools represent a lexicographic response to the needs of translators of specialised texts and are the result of a joint project of teams from the Centre for Lexicography at Aarhus University in Denmark and the International Centre for Lexicography at the University of Valladolid in Spain, involving lexicographers and accounting experts. The dictionaries integrate information technology and techniques with usage-based theories and provide help that can satisfy the needs for information when people are engaged in specific types of usage situations, including the translation of specialised texts. 
The dictionaries use specific lexicographic and technological options for creating interaction between database and dictionary. The database contains carefully selected data types in discrete data fields. Users consult a dictionary through the homepage and the dictionary sends their queries to the database through a search engine that looks for matches in the database. Once found, the data are sent to the dictionary and presented to users in a predetermined way (Nielsen \& Almind 2011: 155-166). This set-up allows users to access the data in the database in a number of ways that are designed to provide data giving help to users in different but specific types of usage situations (see Nielsen \& Fuertes-Olivera, 2013, for a description).

The dictionaries are intended to help three groups of Danish and Spanish users: (1) translators and language staff; (2) accounting experts and semi-experts; and (3) students and laypersons interested in accounting matters. Translating is usually done by persons within the first of these groups and translation students from the third group with various levels of competence. In brief, translators and language staff generally have a relatively high level of general linguistic competence, a low to medium competence level in accounting discourse, a low to medium level of factual accounting competence, a high level of translation competence, and a medium to high level of competence in producing general texts in their native language as well as a foreign language. Their competence level of translating specialised texts into or from a foreign language will range from low to high. Students can generally be assumed to have a low to medium level of competence across the board and therefore share many levels of competence with translators and language staff (Fuertes-Olivera \& Nielsen 2012).

The translation dictionaries are revised and updated periodically and each contains approximately 7,500 lemmas, including single-word and multi-word units (e.g. 'netting' and 'equity attributable to equity shareholders of the parent'). Furthermore, each dictionary contains more than 20,000 collocations and phrases and between 1,000 and 2,000 examples, all with translations in order to help users translate accounting texts.

The access routes chosen by users determine which types of data will be presented in the dictionary. By focusing on helping with the translation of terms and associated word combinations, lexicographers can ensure that data are retrieved which satisfy needs of translators and that the data are presented so that they can easily be turned into useful information. The translation dictionaries offer users two search options: users can search for help to translate an accounting term, and help to translate a collocation or phrase. When consulting a dictionary, users go to the appropriate dictionary website linked 
to a search engine that searches the database and retrieves the relevant data, which will be presented to the users in a prearranged manner depending on the search option selected.

\subsection{El Diccionario Inglés-Español de Contabilidad: Traducción}

The Diccionario Inglés-Español de Contabilidad: Traducción (Fuertes-Olivera et al. 2012a) is a component of the Accounting Dictionaries that helps professional and would-be translators (e.g. students) to translate an English accounting term into Spanish. This has resulted in the inclusion of dictionary data that help to disambiguate the English meaning in a precise way, offer one (and only one) Spanish equivalent, describe the grammar and inflection of the English terms and their Spanish equivalents, and illustrate how the term is used in English and Spanish contexts. For instance, when users search for financial income, the system retrieves the following data:

\section{An English definition that contains two full sentences}

Financial income refers to income in the form of dividends, interest accrued on funds invested and interest paid by borrowers as well as other income earned in relation to loans and guarantees, e.g. in the form of fees. Financial income is recognized in the profit and loss account as a separate item or as part of the item net financials.

This definition not only describes the meaning of the term in a way that translators understand but it also offers some contextual and knowledge clues, e.g. "Financial income is recognized in the profit and loss account as a separate item or as part of the item net financials". This informs users of the existence of profit and loss account, which is an accounting genre that consists of items such as financial income or net financials.

2. Its Spanish equivalent: ingreso financiero preceded by the Arabic number '2'

This is an insertable equivalent, i.e., a Spanish accounting term that can be included in any Spanish accounting sentence. The Arabic number indicates that ingreso financiero is polysemous, in contrast to financial income, which has one meaning in English. (In Spanish accounting texts, an ingreso financiero can also be part of the income an insurance company obtains in connection with its capital investment. Its English counterpart is financial profit of the insurer). 
3. The Spanish translation of the English definition, also worded in two sentences

El ingreso financiero se refiere al ingreso procedente de dividendos, intereses devengados procedentes de fondos invertidos e intereses pagados por prestatarios así como otros ingresos recibidos procedentes de préstamos y garantías, por ejemplo en forma de honorarios. El ingreso financiero se reconoce en la cuenta de pérdidas y ganancias como una partida separada o como parte de la partida resultado financiero neto.

This definition helps Spanish users with poor English knowledge to understand the exact meaning of financial income and its Spanish equivalent ingreso financiero. Furthermore, it offers users a key item of contextual translation information: "Financial income is recognized" is translated as a Spanish se-passive instead of a Latin passive (i.e., "El ingreso financiero se reconoce" instead of "El ingreso financiero es reconocido"), as we believe that Spanish se-passives are more frequent and natural in Spanish specialised texts than Latin passives.

4. Inflection and grammar data for the English term and its Spanish equivalent noun: <a financial income, the financial income, financial incomes> nombre masculino <un ingreso financiero, el ingreso financiero, unos ingresos financieros, los ingresos financieros>

These types of data indicate that term and equivalent are nouns (the Spanish one is masculine), can be in singular and plural form and can go with definite and indefinite articles.

5. Three English collocations and their Spanish translations (the font is in different colours for each language)

- financial income and expenses

- ingresos y gastos financieros

- financial income from group enterprises

- el ingreso financiero de las empresas del grupo

- other financial income

- otro ingreso financiero

The collocations offer key contextual clues: (i) the English financial income and expenses is worded in a different order in Spanish, i.e., it is ingresos y gastos financieros. This Spanish word order is idiomatic and it would be unnatural 
to use the English word order ingresos financieros y gastos; (ii) the use of the article las in Spanish demands the presence of the article el as Spanish tends to use articles more than English does (the translation ingreso financiero de empresas del grupo would be unnatural).

6. An English example and its Spanish translation (the font being in different colours for each language)

- Financial income in 2005 rose by GBP500m compared with GB$\mathrm{P} 1,600 \mathrm{~m}$ in 2004.

- Al compararlo con los 1.600 millones de libras esterlinas del 2004, el ingreso financiero del 2005 se incrementó en 500 millones de libras esterlinas.

The translation rendered has avoided the use of syntactic or rhetoric calquing, i.e., the maintenance of the English theme/rheme and syntax with Spanish words. The Spanish translation has modified the thematic structure of the English sentence and has used a passive sentence with the aim of emphasising the non-human character of the English subject.

\subsection{El Diccionario Inglés-Español de Contabilidad: Traducción de Frases y Expresiones}

The Diccionario Inglés-Español de Contabilidad: Traducción de Frases y Expresiones (Fuertes-Olivera et al. 2012b) is also a component of the Accounting Dictionaries that helps professional and would-be translators (e.g. students) to translate English accounting expressions into Spanish. The term expression refers to the term collocation, which is used in the Accounting Dictionaries as an umbrella term for referring to word combinations that are typical for the kind of language in question, and which can be useful for re-using in text production or for assisting in translation. They are composed of two or more orthographic words, do not constitute a full sentence, but offer potential users the possibility of obtaining relevant information (Fuertes-Olivera et al. 2012c). The term frase refers to an example sentence, i.e., a full sentence that illustrates the use of a specific term.

Both examples and collocations (frases y expresiones) assist translators because they are integral parts of domain-specific consensual usage in both source and target language. They help translators to differentiate semantic and syntactic properties which are caused by specific referencial foci within the factual structure of domains in different languages. For example, accounting principle can be a term (principio contable in Spanish), an integral part of 
a longer term (e.g., generally accepted accounting principles; Spanish principios contables generalmente aceptados), or part of a sequence of words that happens to occur together (e.g. cost accounting principles; Spanish: principios de la contabilidad de costes). A search in this dictionary would retrieve these three uses of accounting principle, which is an innovative lexicographical solution that aims to assist translators, for example professional translators whose emails and comments on the usability and reliability of this dictionary are very positive, perhaps because this dictionary offers them around 20,000 English collocations translated into Spanish, and around 2,000 English examples translated into Spanish.

When a user searches specifically for collocations and examples of financial income in this dictionary, he or she will retrieve 9 instances of English collocations or examples and their corresponding Spanish translations. Some of them could be converted into useful information:

(1) dividends and other financial income received (IAS/IFRS) dividendos y otros ingresos financieros recibidos

This collocation indicates that it was extracted from the International Accounting Standards/International Financial Reporting Standards (IAS/IFRS), i.e., it is international accounting English. It also shows that financial income is part of the multiword term other financial income, which is an item in the profit and loss account that recognises interest income from investments, dividends, foreign exchange gains and similar income. The English multiword term has an insertable Spanish multiword equivalent that typically occurs in the plural otros ingresos financieros; this shows a grammar difference between the two languages.

(2) current year net financial income or expense resultado financiero neto del año actual

This collocation indicates that financial income is part of an English multiword term: financial income or expense, whose Spanish equivalent, resultado financiero, shows that the words used in association with terms may differ from one language to another; this illustrates a cultural difference between the two languages.

(3) total net financial income total ingreso financiero neto

Both the English collocation and its Spanish translation are examples of accounting discourse and the translation illustrates this by placing Spanish total at the beginning and not at the end, which is the natural position for Spanish adjectives; this illustrates the influence of English, which is the lingua 
franca of accounting (Fuertes-Olivera \& Nielsen 2011), on Spanish accounting language.

(4) Income classified as other operating income, financial income and extraordinary income in company accounts is excluded from turnover. Los ingresos clasificados como otros ingresos de explotación, ingresos financieros e ingresos extraordinarios en las cuentas de la empresa están excluidos de la facturación.

This translation explains the existence of a subtle difference between English and Spanish accounting language. Spanish typically uses plural forms whereas English uses singular ones; this indicates that the linguistic structures of the source and target language are different and therefore Spanish uses articles such as Los, las and la (twice) whereas there are no articles in English.

\section{Conclusion}

This article offers a description of the concept user needs that is used in the Function Theory of Lexicography. This concept demands the design of information tools that can be accessed and consulted easily and with a view to meeting punctual information needs occurring for specific types of users in specific types of extra-lexicographical situations. Within this approach, the term dictionary encompasses any kind of information tool that is designed for meeting users' needs.

In the era of the Internet, this has resulted in proposing two broad definitions of dictionary. Firstly, a dictionary is a lexicographic reference work containing dictionary articles related to individual topics or elements of language, and possibly one (or more) external texts, which can be consulted if users need assistance in specific usage situations. Secondly, a dictionary is a lexicographic reference work that consists of several dictionaries, each of which contains dictionary articles related to individual topic or language elements, and possible one (or more) external texts, which can be consulted if users need assistance in specific usage situations.

The Accounting Dictionaries illustrate the viability of both definitions of the term dictionary. They are a set of several individual dictionaries, some of which are especially designed for assisting translators of accounting texts. One of them is the Diccionario Inglés-Español de Contabilidad: Traducción, which primarily aims to assist translators with translating English accounting terms into Spanish. Hence, each dictionary entry contains a number of dictionary data that make the meaning of the term precise, and offer one insertable equivalent as well as grammar data and inflexions. The dictionary also 
shows the use of the term in context by means of several English collocations and examples translated into Spanish.

The second dictionary discussed is the Diccionario Inglés-Español de Contabilidad: Traducción de Frases y Expresiones. This dictionary is especially adequate for illustrating the use of lexical combinations in various contexts. Translators need collocations and expressions because they are integral parts of domain-specific consensual usage in both source and target languages, and show differences in semantic and syntactic properties caused by specific referential foci within the factual structure of accounting.

This article illustrates the working of both dictionaries with the term financial income. When searching in Diccionario Inglés-Español de Contabilidad: Traducción, users retrieve the definitions, equivalents, grammar and inflectional data of the English term as well as specific uses of the term in collocations and examples. All the data retrieved focus on the exact meaning of the English term and its use in context. When searching in the Diccionario Inglés-Español de Contabilidad: Traducción de Frases y Expresiones, the users retrieve all the instances of English collocations and examples and their Spanish translations in which financial income occurs. All the data retrieved focus on context and usage in the domain of accounting. In addition, all of them can be used as instances of translations made by professional translators. In sum, these two dictionaries are the result of applying the tenets of the Function Theory of Lexicography and target the specific needs translators may have when they are translating English accounting texts into Spanish.

\section{Acknowledgments}

Thanks are due to Ministerio de Economía y Competitividad and Junta de Castilla y León for financial support (grants FFI2011-22885 and VA067A12-1). Thanks are also due to the Velux Foundation and to Aarhus University, Department of Business Communication, Centre for Lexicography (Business and Social Science) for financial support.

\section{References}

BeLL, Roger T. (2000) Translation and Translating. Theory and Practice. $11^{\text {th }}$ printing. London \& New York: Longman.

BERGENHOLTZ, Henning. (2012) "What is a dictionary?" Lexikos 26, pp. 20-30.

BergenHolTZ, Henning \& Uwe Kaufmann. (1997) "Terminography and Lexicography. A Critical Survey of Dictionaries from a Single Specialised Field." Hermes. Journal of Linguistics 18, pp. 91-125. 
BergenHOlTZ, Henning \& Sandro Nielsen. (2006) "Subject-field Components as Integrated Parts of LSP Dictionaries.” Terminology 12:2, pp. 281-303.

Bergenholtz, Henning \& Sven Tarp. (2002) "Die moderne lexikographische Funktionslehre. Diskussionsbeitrag zu neuen und alten Paradigmen, die Wörterbücher als Gebrauchsgegenstände verstehen.” Lexicographica 18, pp. 253-263.

Bergenholtz, Henning \& Sven Tarp. (2003) "Two Opposing Theories: On H.E. Wiegand's Recent Discovery of Lexicographic Functions." Hermes. Journal of Linguistics 31, pp.171-196.

Bergenholtz, Henning \& Sven Tarp. (2004) "The Concept of Dictionary Usage." Nordic Journal of English Studies 3, pp. 23-36.

BERGENHOlTZ, Henning \& Sven Tarp. (2010) "LSP Lexicography or Terminography? The Lexicographer's Point of View." In: Fuertes-Olivera, Pedro A. (ed.) Specialised Dictionaries for Learners. Berlin \& New York: De Gruyter, pp. 27-38.

DANCETTE, Jeanne. (2011) "Lintégration des Relations Sémantiques dans les Dictionnaires Spécialisés Multilingues: du corpus ciblé à l'organisation des connaissances.” Meta 56:2, pp. 284-300.

DAvidSOn, Peter M. (1991) "Computerised Terminological Databases for Translators who Use Word Processors." Meta 36:2-3, pp. 424-430.

Fuertes-Olivera, Pedro A. (ed.) (2010) Specialised Dictionaries for Learners. Berlin \& New York: De Gruyter.

Fuertes-Olivera, Pedro A. (2012): "Lexicography and the Internet as a Re(source)." Lexicographica 28, pp. 49-70.

Fuertes-OliverA, Pedro A. \& Henning Bergenholtz (eds.) (2011) [2013] e-Lexicography: The Internet, Digital Initiatives and Lexicography. London \& New York: Continuum. Reprinted in 2013.

Fuertes-Olivera, Pedro A. \& Sandro Nielsen. (2011) “The Dynamics of Terms in Accounting: what the Construction of the Accounting Dictionaries Reveals about Metaphorical Terms in Culture-bound Subject Fields." Terminology 17:1, pp. 157-180.

Fuertes-Olivera, Pedro A. \& Sandro Nielsen. (2012) "Online Dictionaries for Assisting Translators of LSP Texts: The Accounting Dictionaries." International Journal of Lexicography 25:2, pp. 191-215.

Fuertes-Olivera, Pedro A. \& Sven Tarp. (2014) Theory and Practice of Specialised Online Dictionaries. Lexicography versus Terminography. Berlin \& New York: De Gruyter.

Fuertes-Olivera, Pedro A.; Henning Bergenholtz; Sandro Nielsen; Pablo Gordo Gómez; Lise Mourier; Marta Niño Amo; Ángel de los Ríos Rodicio; Ángeles Sastre Ruano; Sven Tarp \& Marisol Velasco Sacristán. (2012a) Diccionario 
Inglés-Español de Contabilidad: Traducción. Data base and Design: Richard Almind \& Jesper Skovgård Nielsen. Odense: Lemma.com.

Fuertes-Olivera, Pedro A.; Henning Bergenholtz; Sandro Nielsen; Pablo Gordo Gómez; Lise Mourier; Marta Niño Amo; Ángel de los Ríos Rodicio; Ángeles Sastre Ruano; Sven Tarp \& Marisol Velasco Sacristán. (2012b) Diccionario Inglés-Español de Contabilidad: Traducción de Frases y Expresiones. Data base \& Design: Richard Almind \& Jesper Skovgård Nielsen. Odense: Lemma.com. Fuertes-Olivera, Pedro A.; Henning Bergenholtz; Sandro Nielsen \& Marta Niño Amo. (2012c) "Classification in Lexicography: The Concept of Collocation in the Accounting Dictionaries." Lexicographica 28, pp. 291-305.

HAENSCH, Günther. (1991) "Die zweisprachige Fachlexikographie und ihre Probleme." In: Hausmann, Franz Josef; Oskar Reichmann; Herbert Ernst Wiegand \& Ladislav Zgusta (eds.) 1991 Dictionaries. An International Encyclopedia of Lexicography, vol. 3. Berlin \& New York: Walter de Gruyter, pp. 2937-2948.

HousEHOLDER, Fred W. (1962) "Summary report." In: Householder, Fred W. \& Sol Saporta (eds.) 1962 Problems in Lexicography. Bloomington: Indiana University Press, pp. 279-282.

Humblé, Philippe. (2010) "Dictionnaires et traductologie : le paradoxe d'une lointaine proximité." Meta 55:2, pp. 329-337.

Josselin-Leray, Amelie \& Roda P. Roberts. (2005) "In Search of Terms: An Empirical Approach to Lexicography." Meta 50:4.

LAURÉN, Christer. (1993) Fackspråk. Form, innhåll, function [Specialised Language. Form, content, function]. Lund: Studenterlitteratur.

LHomme, Marie-Claude. (2006) "The Processing of Terms in Dictionaries: New Models and Techniques." Terminology 12:2, pp. 181-188.

NiELSEN, Sandro. (1990) "Contrastive Description of Dictionaries Covering LSP Communication." Fachsprache/International Journal of LSP 3-4, pp. 129-136.

NiELSEN, Sandro. (2008) "The Effect of Lexicographical Information Costs on Dictionary Making and Use." Lexikos 18, pp. 170-189.

Nielsen, Sandro \& Richard Almind. (2011) "From Data to Dictionary. In: Fuertes-Olivera, Pedro A. \& Henning Bergenholtz (eds,) 2011 e-Lexicography: The Internet, Digital Initiatives and Lexicography. London \& New York: Continuum, pp. 141-167.

NiElSEn Sandro \& Pedro A. Fuertes-Olivera. (2013) "Developments in Lexicography: From Polyfunctional to Monofunctional Accounting Dictionaries." Lexikos 23 (To appear).

NORD, Christiane. (2005) Text Analysis in Translation. Theory, Methodology, and Didactic Application of a Model for Translation-Oriented Text Analysis. Amsterdam \& New York: Rodopi.

PIMENTEL, Janine; Marie-Claude L'Homme \& Marie-Ève Laneville. (2012) "General and Specialized Lexical Resources: A Study on the Potential of Combining 
Efforts to Enrich Formal Lexicons". International Journal of Lexicography 25:2, pp. 152-190.

TARP, Sven. (2008) Lexicography in the Borderland between Knowledge and Non-Knowledge. General Lexicographical Theory with Particular Focus on Learner's Lexicography. Tübingen: Niemeyer.

TARP, Sven. (2009) "Reflections on Lexicographic User Research." Lexikos 19, pp. 275-296.

Tono, Yukio. (2010) "A Critical Review of the Theory of Lexicographical Functions." Lexicon 40, pp. 1-26.

\section{BIONOTES / NOTAS BIOGRÁFICAS}

Dr. Pedro A. Fuertes-Olivera is Head of the International Centre for Lexicography at the University of Valladolid. He is also a Tutor at the Spanish Open University (Palencia). His interest lies in specialised lexicography, translation, and language teaching. He was "Velux Visiting Professor 2011-2012" at the Centre for Lexicography at the School of Business and Social Sciences at the University of Aarhus. He has been keynote/plenary speaker in conferences held in Austria, Canada, China, Denmark, Germany, Namibia, South Africa, Spain, and the United States. He is currently the Principal Investigator of several funded research projects, co-author of Pedagogical Specialised Lexicography (John Benjamins, 2008), and Theory and Practice of Specialised Online Dictionaries. Lexicography versus Terminography (De Gruyter, 2014), editor of Specialised Dictionaries for Learners (De Gruyter, 2010), and co-editor of e-Lexicography: The Internet, Digital Initiatives and Lexicography (Continuum, 2011, and Bloomsbury, 2013). He has also co-edited several specialised dictionaries.

El doctor Pedro A. Fuertes Olivera es el director del Centro Internacional de Lexicografía de la Universidad de Valladolid. Es tutor de la UNED (Palencia), profesor Velux 2011-2012 en el Centre for Lexicography de la Universidad de Aarhus (Dinamarca). Fuertes Olivera trabaja en la actualidad en aspectos relacionados con la lexicografía especializada, la traducción y la enseñanza del ESP. Ha impartido seminarios y conferencias plenarias en congresos y reuniones científicas celebradas en Austria, Canadá, China, Dinamarca, Alemania, Namibia, Sudáfrica, España y los Estados Unidos. Es investigador principal de varios proyectos financiados, coautor de Pedagogical Specialised Lexicography (John Benjamins, 2008) y Theory and Practice of Specialised Online Dictionaries. Lexicography versus Terminography (De Gruyter, 2014), editor 
de Specialised Dictionaries for Learners (De Gruyter, 2010), y coeditor de eLexicography: The Internet, Digital Initiatives and Lexicography (Continuum, 2011, y Bloomsbury, 2013). Es coeditor de varios diccionarios.

Dr. Sandro Nielsen is affiliated with the Department of Business Communication, School of Business and Social Sciences, Aarhus University, Denmark, where he is Associate Professor, and affiliated with the International Centre for Lexicography, University of Valladolid, Spain. He has an MA in English (LSP for translators and interpreters) from 1987 and was awarded his PhD degree in specialized lexicography in 1992. He has published extensively on theoretical and practical lexicography, and is the author of The Bilingual LSP Dictionary. Principles and Practice for Legal Language (Narr, 1994), co-editor of Lexicography in the $21^{\text {st }}$ Century (Benjamins, 2009), Lexicography at a Crossroads (Lang, 2009), a printed and an online bilingual law dictionary, three printed and more than twenty online accounting dictionaries, and a contributor to the Manual of Specialised Lexicography. His main research areas are principles for online LSP dictionaries, user guides in dictionaries, lexicographic information costs and academic dictionary reviewing. His teaching interests focus on lexicography and legal translation for translators and interpreters.

El doctor Sandro Nielsen pertenece al Department of Business Communication, School of Business and Social Sciences (Universidad de Aarhus), y al International Centre for Lexicography (Universidad de Valladolid). Tiene un máster en inglés (en traducción especializada para traductores e intérpretes) del año 1987 y es doctor en lexicografía especializada desde el año 1992. Nielsen ha publicado un gran número de estudios, la mayoría de ellos relacionados con la teoría y práctica de la lexicografía. Es autor de The Bilingual LSP Dictionary. Principles and Practice for Legal Language (Narr, 1994), coeditor de Lexicography in the $21^{\text {st }}$ Century (Benjamins, 2009), Lexicography at a Crossroads (Lang, 2009), tres diccionarios impresos y más de 20 diccionarios de Internet y del Manual of Specialised Lexicography. En la actualidad investiga sobre varios aspectos lexicográficos, por ejemplo, los problemas relacionados con los costes de acceso a la información, la revisión y recensión de diccionarios, la confección de guías de usuarios, etc. Su actividad docente se centra en la enseñanza de la lexicografía y de la traducción jurídica para traductores e intérpretes.

Dr. Henning Bergenholtz: Born 1944 in Copenhagen. 1973 M.A. (Technical University of Berlin), 1975 dr. phil. (University of Essen), 1978 dr. habil. (University of Essen), 2009 dr. h.c. (University of Valladolid). From 1973 at 
universities in Bonn, Essen, Cairo, Cologne, Bochum, the Aarhus School of Business (Denmark). 1984 extraordinary professor for German linguistics at the University of Essen, 1987-92 research professor, 1992 professor of bilingual specialized lexicography at the Aarhus School of Business, from 2005 extraordinary professor at the University of Stellenbosch, from 2011 extraordinary professor at the university in Pretoria at the Department for Information Science. From 1996 to 2013 director of the Centre for Lexicography, Aarhus University. From 2013 professor emeritus at the Aarhus University, and member of the International Centre for Lexicography (University of Valladolid). He has published extensively on language grammar, language policy and lexicography, and has been the editor of around 50 dictionaries, and author or co-author of more than 300 academic publications (e.g. Manual of Specialised Lexicography; Lexicography at a Crossroads).

El doctor Henning Bergenholtz nació en 1944 (Copenhague), obtuvo su título de máster en 1973 (Universidad Técnica de Berlín), su título de doctor en 1975 (Universidad de Essen), su habilitación en 1978 y un doctorado honoris causa en 2009 (Universidad de Valladolid). Ha sido profesor desde el año 1973 en las universidades de Bonn, Essen, El Cairo, Colonia, Bochum y la Aarhus School of Business (Dinamarca). En 1984 era profesor extraordinario de Lingüística alemana en la Universidad de Essen, durante 1987-92, profesor de investigación, en 1992 fue nombrado profesor de lexicografía especializada bilingüe en la Aarhus School of Business; desde 2005 es profesor extraordinario en la Universidad de Stellenbosh, desde 2011 es profesor extraordinario de la Universidad de Pretoria (Departamento de Information Science). En la actualidad es profesor emérito en la Universidad de Aarhus. Fue el director del Centre for Lexicography (Universidad de Aarhus) y en la actualidad pertenece al International Centre for Lexicography (Universidad de Valladolid). Bergenholtz es autor de más de 300 obras académicas, entre las que se incluyen manuales, diccionarios y monografías, como por ejemplo su Manual of Specialised Lexicography; Lexicography at a Crossroads). 